
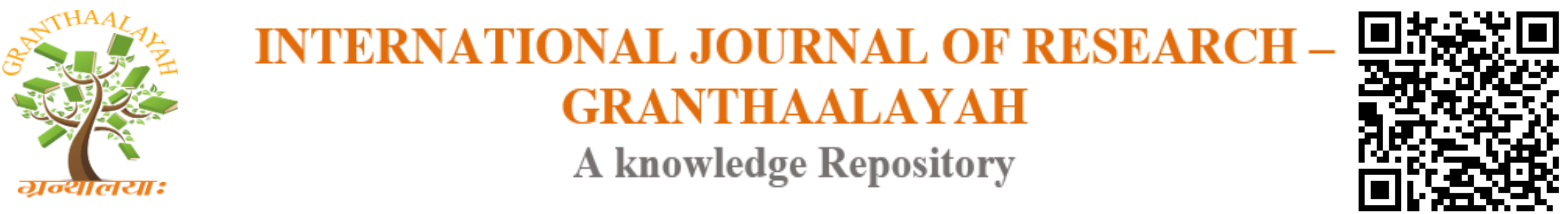

Management

\title{
PERCEPTION OF PEOPLE ON AADHAAR (LINKAGE, USAGE \& VOTING) A CASE STUDY (2014-16) WITH REFERENCE TO CHITTOOR DISTRICT AP, INDIA
}

\author{
Dr. K V V Raaju ${ }^{* 1}$ \\ ${ }^{*}$ Senior Assistant Professor, Madanpalli Institute of Technology and Sciences, Madanpalli, \\ Chittor District, AP, India
}

UGC Sponsored Minor Research Project Proposal 829

\begin{abstract}
This article is a survey done to know how the people linked their aadhaar number to the voter id, gas cylinder, fee reimbursement, Bank account, House \& Water tax, Birth Certificate, Admission in a School, RTO license, Raitu Runa Mafi, Employer data, Income/Caste/ Nativity. This article also collected the information on how is the usage of aadhaar as a proof of identity and the people voting on continue the aadhaar and linking of aadhaar.

Keywords: Aadhaar; Unique Identification Number; Enrollment; Perception.

Cite This Article: Dr. K V V Raaju. (2017). "PERCEPTION OF PEOPLE ON AADHAAR (LINKAGE, USAGE \& VOTING) A CASE STUDY (2014-16) WITH REFERENCE TO CHITTOOR DISTRICT AP, INDIA.” International Journal of Research - Granthaalayah, 5(7), 450-460. https://doi.org/10.29121/granthaalayah.v5.i7.2017.2153.
\end{abstract}

\section{Introduction}

The Unique Identification Number aadhaar card is a prestigious project introduced by Central Government. The objective of aadhaar is to link all the people of India. From the starting point of its implementing and now the total money spent on this project is 5630 cores. Totally 78.65 cores aadhaar numbers are allotted. This information given by the parliament on May $13^{\text {th }} 2015$. The total amount approved for the project for the year 2009-2017 is 13,633.22 crores (source Economic times March, 2013). ${ }^{1}$ Linking of aadhaar numbers is restricted by the supreme court to LPG subsidy and for public distribution system. The court has not allowed the Banking, Telecom, and other few sectors have not been linked with aadhaar card. Public are aware of this information. There is a criticism on aadhaar that issue of aadhaar numbers may disturb the right to individuality as per article 21 . The final judgment is not yet delivered by the Supreme Court yet. 
But the Government is linking it still to several programs like Voter Id, Pensions, RTO, Scholar ships, Gas cylinders, Fee Reimbursements, Bank accounts, School Admissions, Death, Birth certificates, Employment details with Employer data, Caste, income and residential certificates . Government now is linking the aadhaar card with all fields. And here it is the situation it is right time to know the people's perception.

\section{Aadhaar Enrolment in Chittoor District AP}

There are three divisions in Chittoor 1. Chittoor division 2. Tirupathi division 3. Madanapalle division. Chittoor district consists of 23 mandals and Tirupathi 16 and Madanapalle 34 mandals totally 73 mandals. In almost all the mandals the enrolment is more than $100 \%$. In most of the places the enrolment is more than the populations. ${ }^{2}$

Total 161 E seva Authorized agents worked on enrolments of aadhaar. The total enrolment of aadhaar done through 2 phases. The total process done through watching the progress reports. Totally40, 24,427 people enrolled out of $41,22,456$ (97.62 percent $)^{3}$

Chittoor district is located in Andhra Pradesh. The place where it is called as Rayalaseema region. Chittoor District is having three divisions called Chittoor, Tirupathi and Madanapalle. The aadhaar is issued the number is for life. Every institutions whether it is private, Government or educational are linked with aadhaar. Aadhaar for niraadhaar. A survey planned with a sample of 400 at $95 \%$ confidence level. In that 50 people opinion analyzed and we got the following results.

Table 1: Showing Percentage of Linking Aadhaar to Voter ID

\begin{tabular}{|l|l|l|l|l|l|}
\hline S.No. & Voter Id & Frequency & Percentage & Valid Percentage & Cumulative \\
\hline 1 & No & 9 & 18 & 18 & 18 \\
\hline 2 & Yes & 41 & 82 & 82 & 100 \\
\hline & Total & 50 & 100 & 100 & \\
\hline
\end{tabular}

(Source: Field Survey)

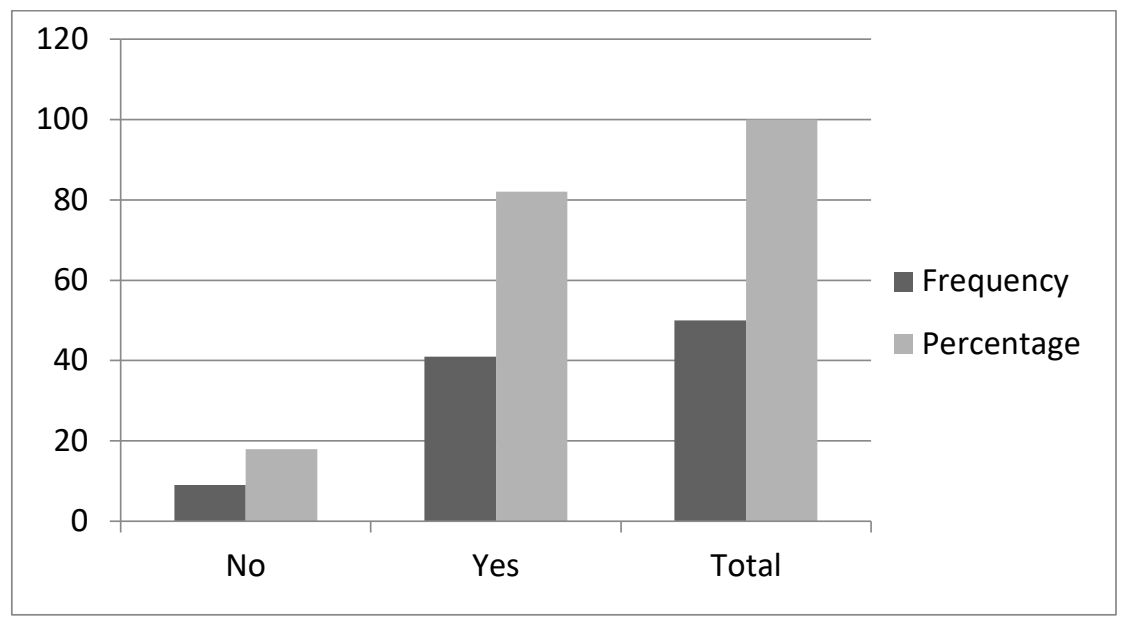

Table 1 shows the linkage of aadhaar number to voter Id. Out of 50, 41 people (82\%) linked with and 9 (18\%) not linked. 
Table 2: Showing Percentage of linking Aadhaar to Gas Cylinder

\begin{tabular}{|l|l|l|l|l|l|}
\hline S.No. & Gas Cylinder & frequency & Percentage & Valid Percentage & Cumulative \\
\hline 1 & No & 20 & 40 & 40 & 40 \\
\hline 2 & Yes & 30 & 60 & 60 & 100 \\
\hline 3 & Total & 50 & 100 & 100 & \\
\hline
\end{tabular}

(Source: Field Survey)

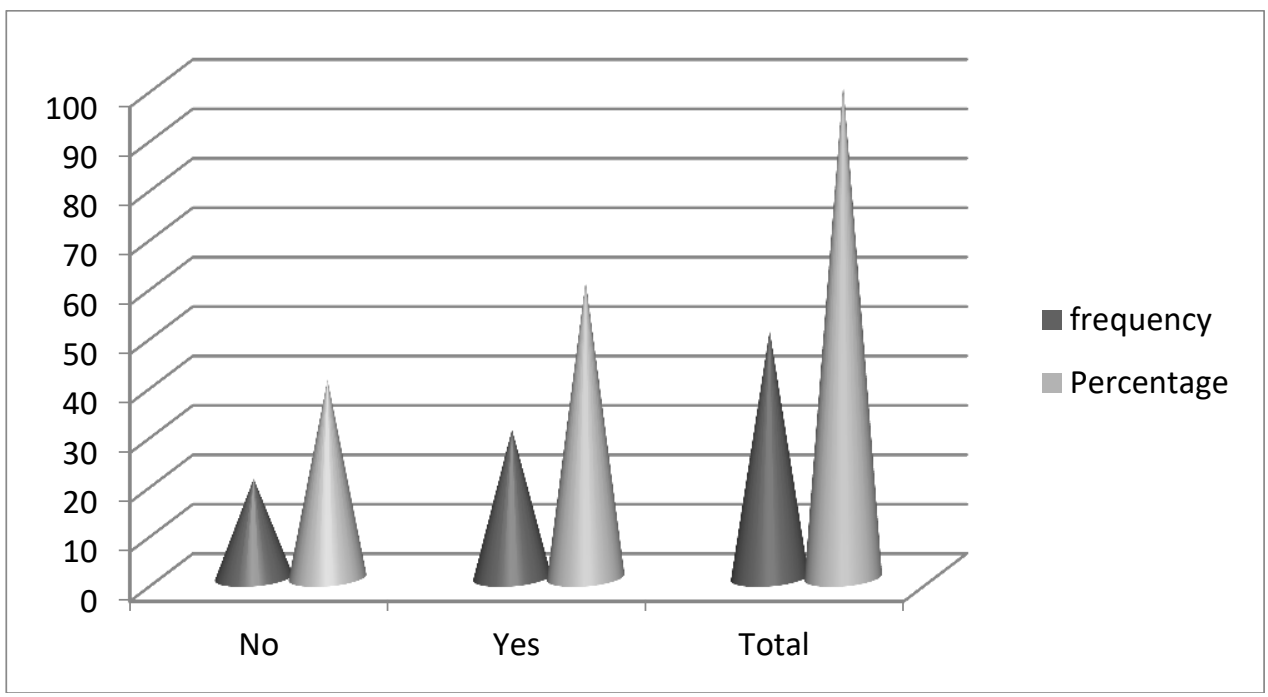

Table 2 shows the linkage of aadhaar number to gas cylinder. Out of 50, 30 people (60\%) linked with and $20(40 \%)$ not linked.

Table 3: Showing Percentage of Aadhaar to linking for Fee Reimbursement

\begin{tabular}{|l|l|l|l|l|l|}
\hline S.No. & Fee Reimbursement & frequency & Percentage & Valid Percentage & Cumulative \\
\hline 1 & No & 27 & 54 & 54 & 54 \\
\hline 2 & Yes & 23 & 46 & 46 & 100 \\
\hline 3 & Total & 50 & 100 & 100 & \\
\hline
\end{tabular}

(Source: Field Survey)

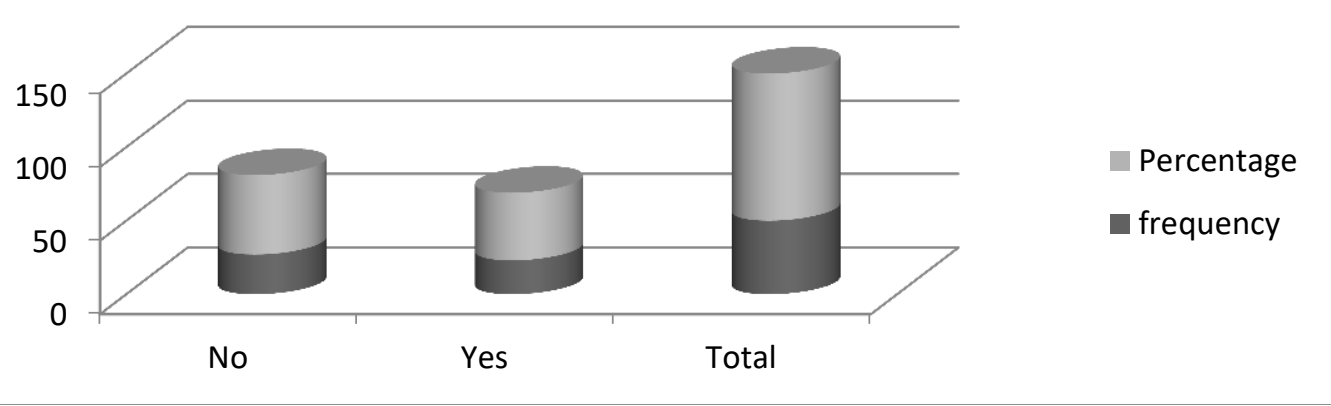

Table 3 shows out of 50, 23 people (46\%) linked Bank account with aadhaar and 27 (54\%) not linked. 
Table 4: showing Percentage of Aadhaar linking to Bank Account

\begin{tabular}{|l|l|l|l|l|l|}
\hline S.No. & \multicolumn{1}{|c|}{ Bank Account } & Frequency & Percentage & Valid Percentage & Cumulative \\
\hline 1 & No & 7 & 14 & 14 & 14 \\
\hline 2 & Yes & 43 & 86 & 86 & 100 \\
\hline 3 & Total & 50 & 100 & 100 & \\
\hline
\end{tabular}

(Source: Field Survey)

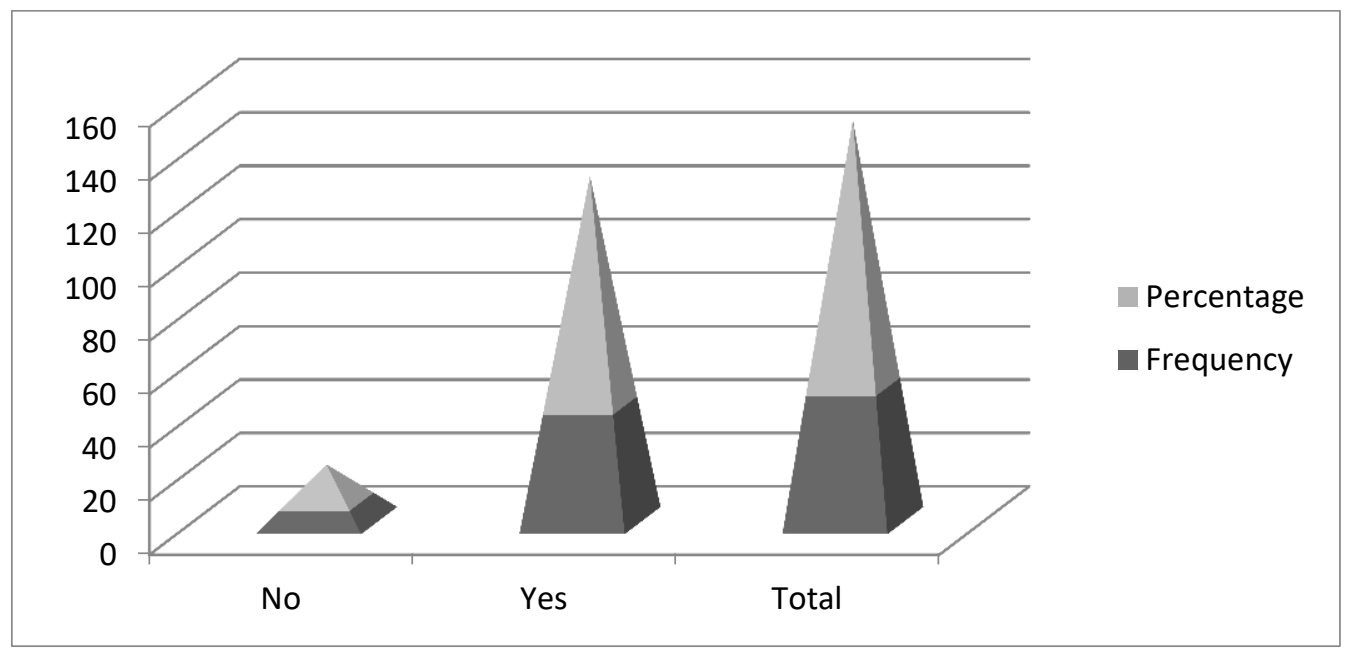

Table 4 shows the linkage of aadhaar to bank account. Out of 50,43(86\%) linked and 7(14\%) not linked.

Table 5: Showing percentage of aadhaar linking to house \& water tax.

\begin{tabular}{|l|l|l|l|l|l|}
\hline Sino & $\begin{array}{l}\text { House \& Water } \\
\text { tax }\end{array}$ & Frequency & Percentage & $\begin{array}{l}\text { Valid } \\
\text { Percentage }\end{array}$ & Cumulative \\
\hline 1 & No & 39 & 78 & 78 & 78 \\
\hline 2 & Yes & 11 & 22 & 22 & 100 \\
\hline & Total & 50 & 100 & 100 & \\
\hline
\end{tabular}

(Source: Field Survey)

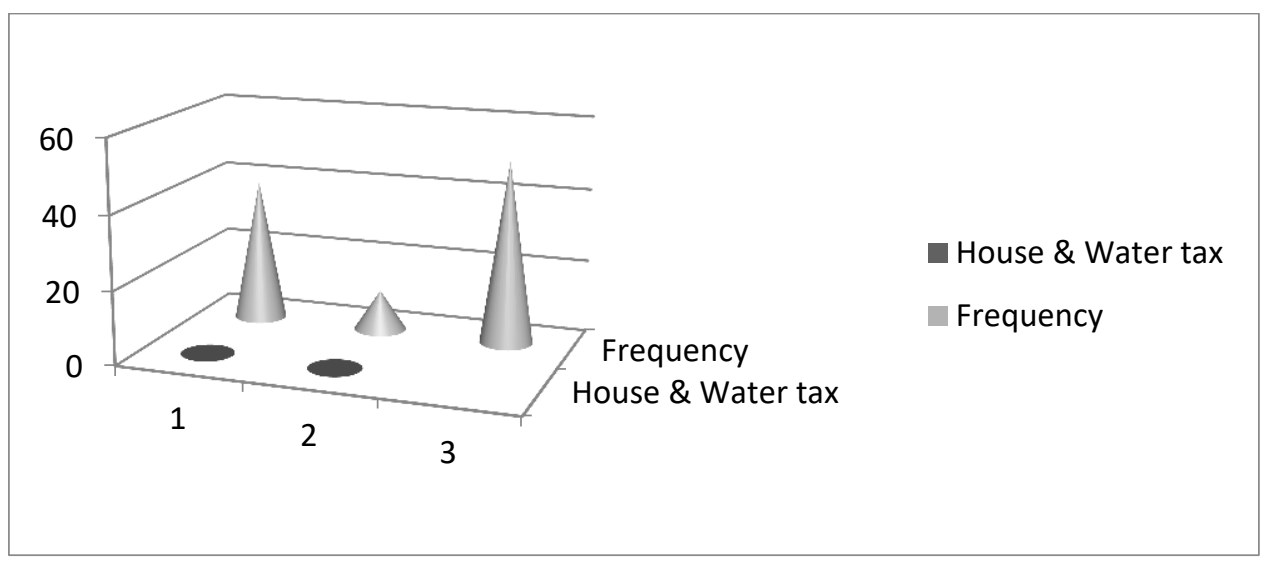

Table 5 shows linkage of aadhaar to house \& water tax, Out of 50, 39(78\%) not linked and 11 (22\%) linked. 
Table 6: Showing Percentage of Aadhaar linking to Birth Certificate

\begin{tabular}{|l|l|l|l|l|l|}
\hline S.No. & Birth Certificate & Frequency & Percentage & Valid Percentage & Cumulative \\
\hline 1 & No & 28 & 56 & 56 & 56 \\
\hline 2 & Yes & 22 & 44 & 44 & 100 \\
\hline 3 & Total & 50 & 100 & 100 & \\
\hline
\end{tabular}

(Source: Field Survey)

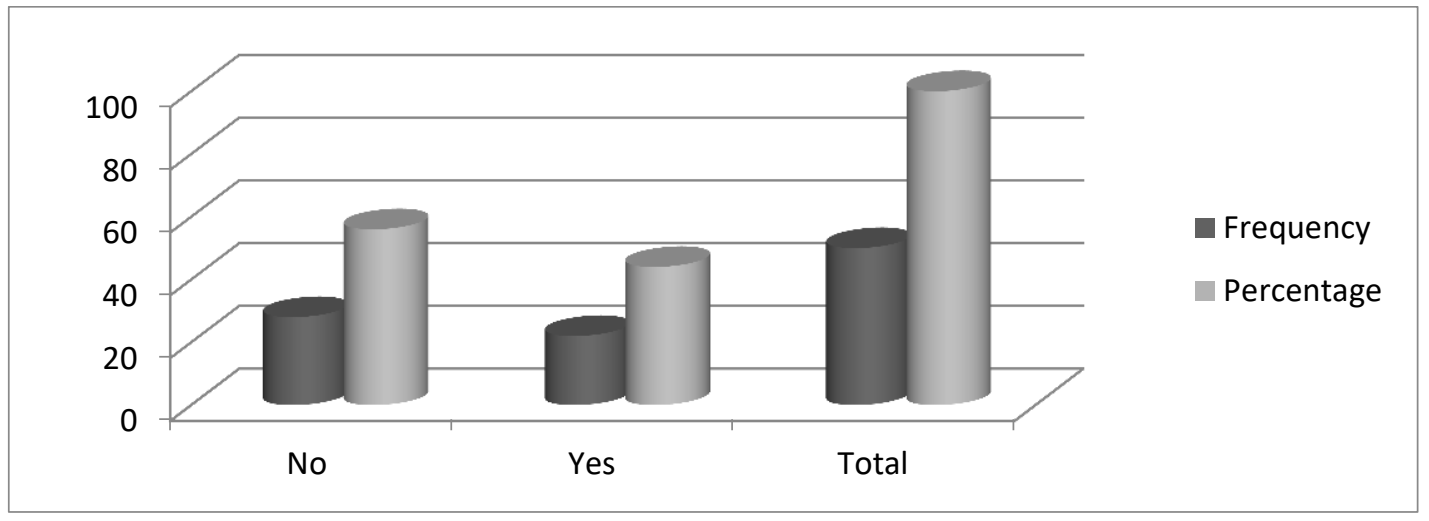

Table 6 shows that for birth certificate 28(56\%) not linked and 22(44\%) linked.

Table 7: Showing Percentage of Aadhaar linking to Admission in a School

\begin{tabular}{|l|l|l|l|l|l|}
\hline S.No. & Admission in a School & Frequency & Percentage & Valid Percentage & Cumulative \\
\hline 1 & No & 35 & 70 & 70 & 70 \\
\hline 2 & Yes & 15 & 30 & 30 & 100 \\
\hline 3 & Total & 50 & 100 & 100 & \\
\hline
\end{tabular}

(Source: Field Survey)

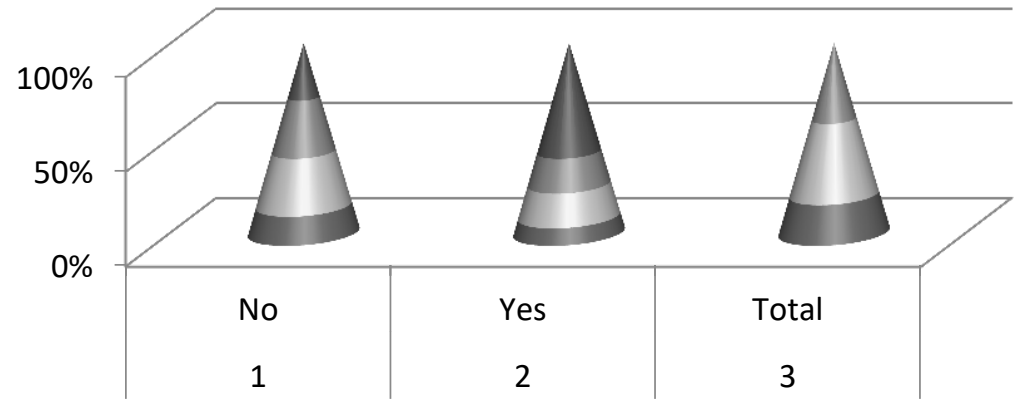

- Cumulative

- Valid Percentage

Percentage

- Frequency

Table 7 shows that for admission in a school $35(70 \%)$ not linked and 15(30\%) linked.

Table 8: Showing Percentage of Aadhaar linking to RTO license

\begin{tabular}{|l|l|l|l|l|l|}
\hline S.No. & RTO License & Frequency & Percentage & Valid Percentage & Cumulative \\
\hline 1 & No & 29 & 58 & 58 & 58 \\
\hline 2 & Yes & 21 & 42 & 42 & 100 \\
\hline 3 & Total & 50 & 100 & 100 & \\
\hline
\end{tabular}

(Source: Field Survey) 


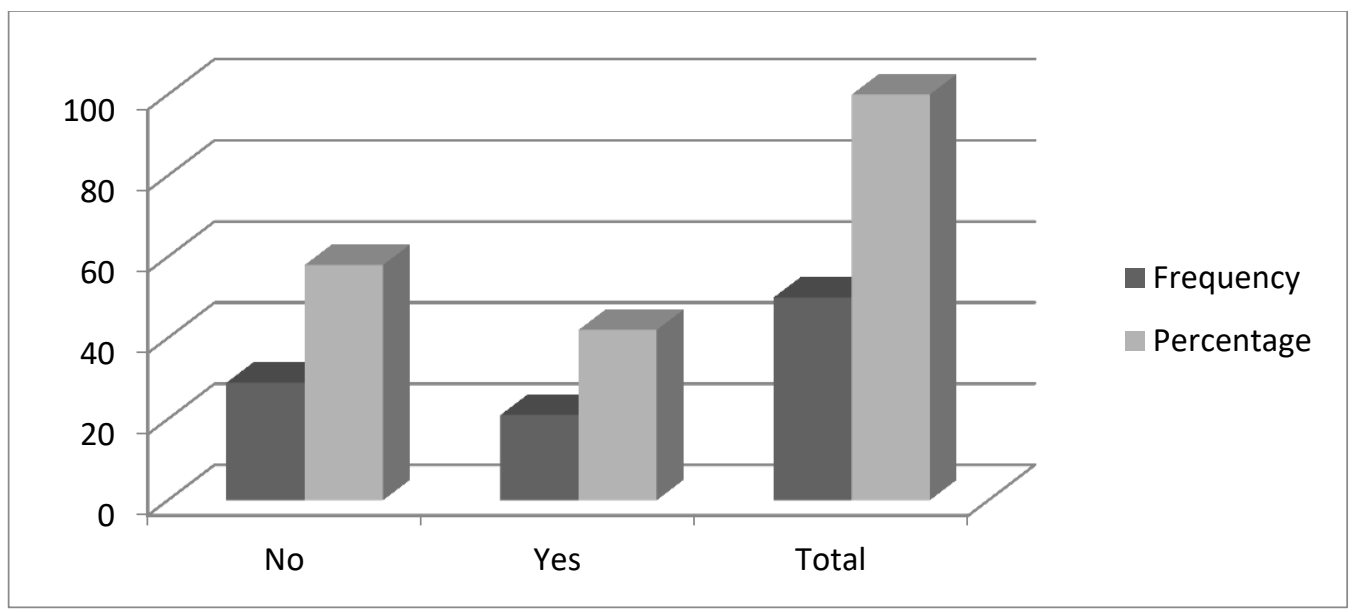

Table 8 shows that for Rto license 29(58\%) not linked and 21(42\%) linked.

Table 9: Showing Percentage of Aadhaar linking to AP Raitu Rune Mafia (agricultural loan)

\begin{tabular}{|l|l|l|l|l|l|}
\hline S.No. & $\begin{array}{c}\text { AP Raito Rune Mafia } \\
\text { (agriculture loan) }\end{array}$ & Frequency & Percentage & $\begin{array}{c}\text { Valid } \\
\text { Percentage }\end{array}$ & Cumulative \\
\hline 1 & No & 44 & 88 & 88 & 88 \\
\hline 2 & Yes & 6 & 12 & 12 & 100 \\
\hline & \multicolumn{2}{|l|}{} & 100 & 100 & \\
\hline
\end{tabular}

(Source: Field Survey)

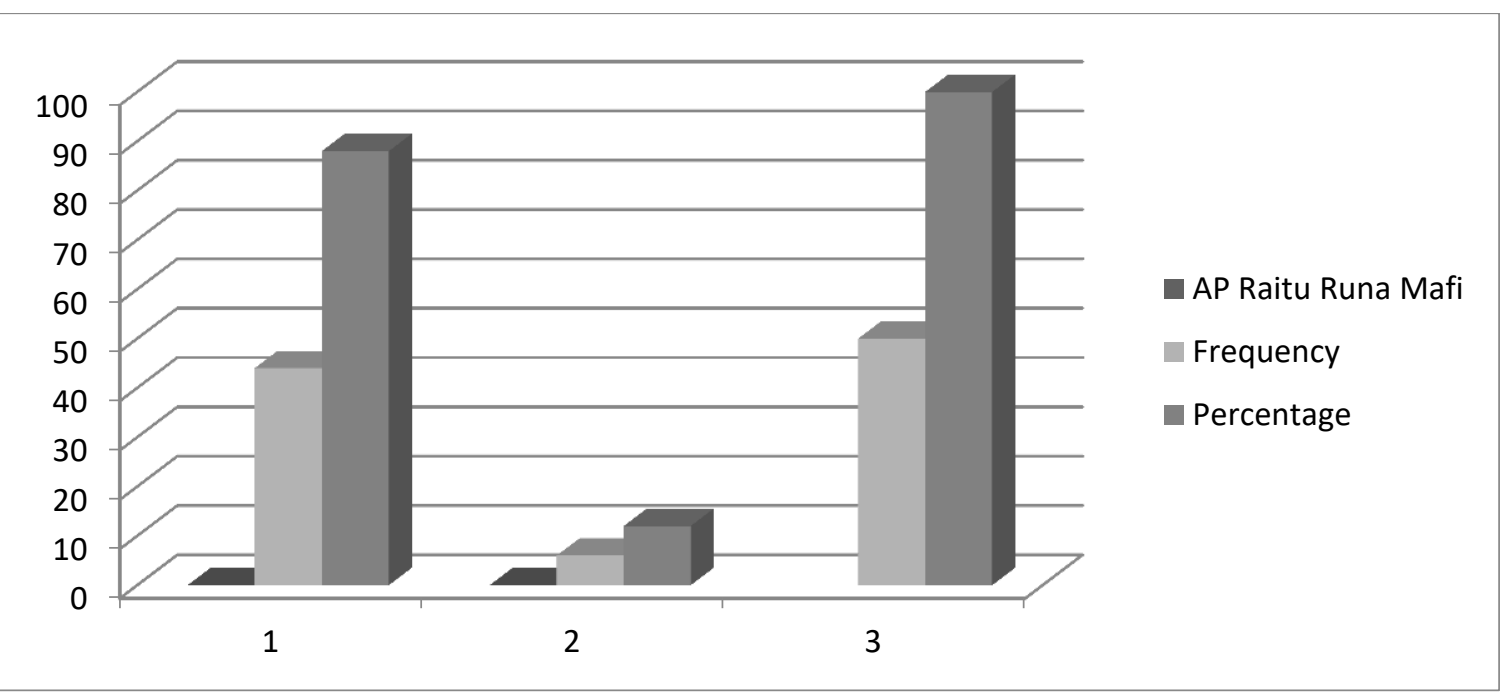

Table 9 shows linking to ratio rune mafia 44(88\%) not linked and $6(12 \%)$ linked

Table 10: Showing the Percentage of Aadhaar linking to Employer data

\begin{tabular}{|l|l|l|l|l|l|}
\hline S.No. & Employer Data & Frequency & Percentage & Valid Percentage & Cumulative \\
\hline 1 & No & 32 & 64 & 64 & 64 \\
\hline 2 & Yes & 18 & 36 & 36 & 100 \\
\hline & Total & 50 & 100 & 100 & \\
\hline
\end{tabular}

(Source: Field Survey) 


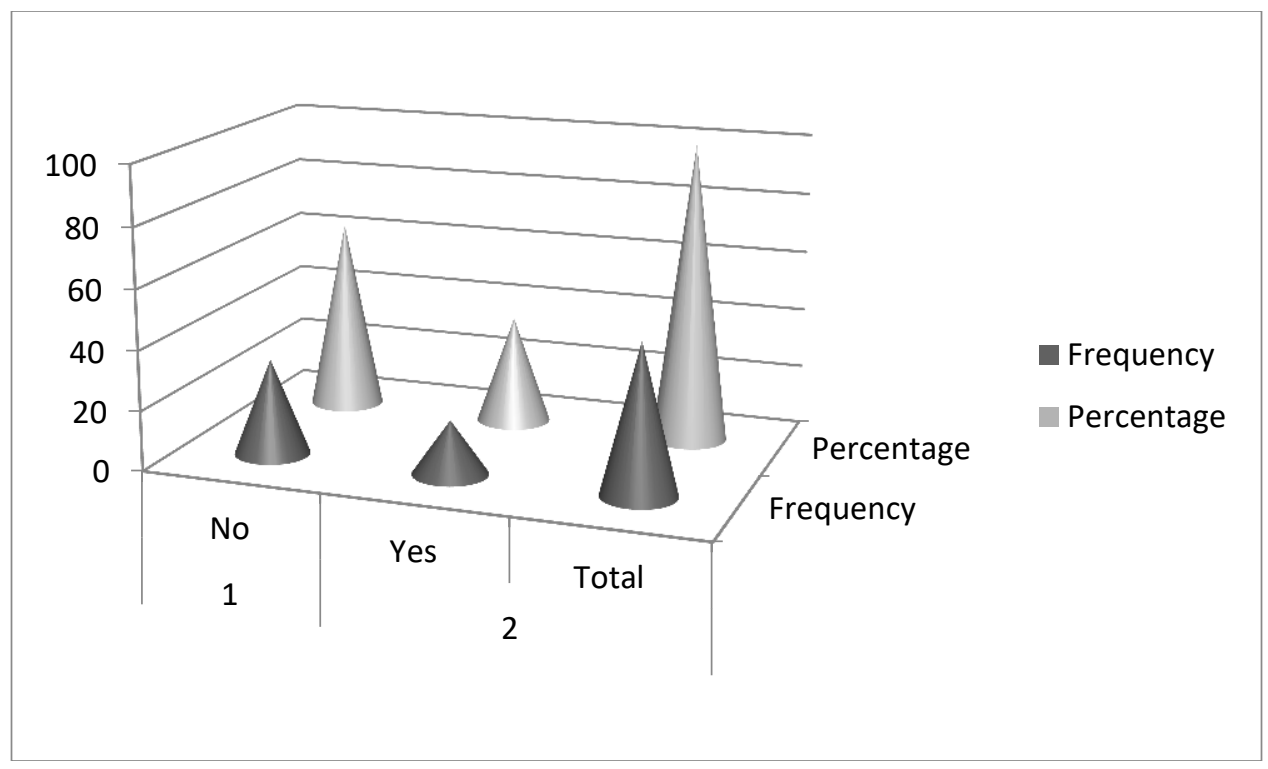

Table 10 shows that linking aadhaar to employer data 32(64\%) not linked and 18(36\%) linked

Table 11: Showing the percentage of linking Aadhaar to Income/Caste/Nativity

\begin{tabular}{|l|l|l|l|l|l|}
\hline S.No. & Income/Caste/Nativity & Frequency & Percentage & Valid Percentage & Cumulative \\
\hline 1 & No & 12 & 24 & 24 & 24 \\
\hline 2 & Yes & 38 & 76 & 76 & 100 \\
\hline & Total & 50 & 100 & 100 & \\
\hline
\end{tabular}

(Source: Field Survey)

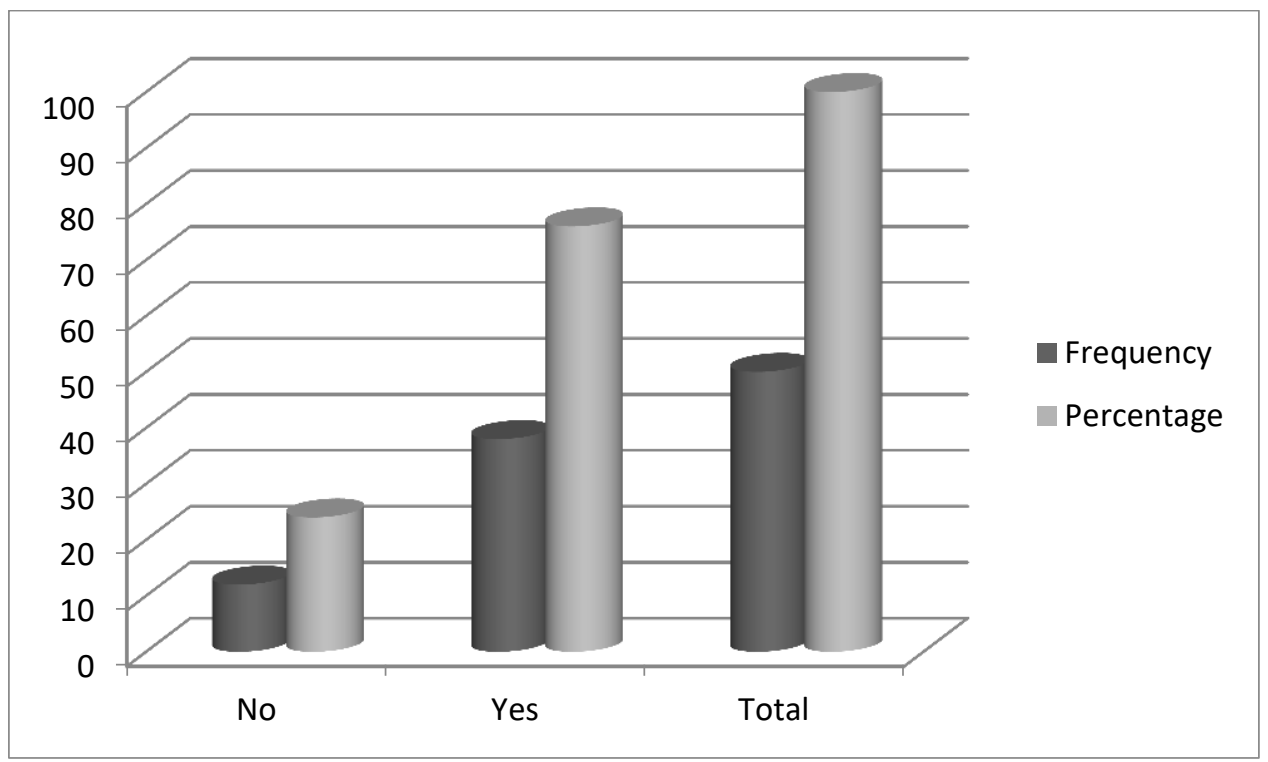

Table 11 shows that linking of aadhaar to caste income nativity $12(24 \%)$ not linked and 38(76\%) linked. 


\section{Total Linked and Unlinked With Percentages}

Linking of aadhaar to voter id, gas cylinder, etc.,

\begin{tabular}{llllll} 
S.No. & \multicolumn{1}{c}{ Item } & Linked & Percentage & Unlinked & Percentage \\
1 & Bank account & 43 & 86 & 14 & 7 \\
2 & Voter Id & 41 & 82 & 9 & 18 \\
3 & Income/Caste/Nativity & 38 & 76 & 12 & 24 \\
4 & Gas cylinder & 30 & 60 & 20 & 40 \\
5 & Fee Reimbursement & 23 & 46 & 27 & 54 \\
6 & Birth Certificate & 22 & 44 & 28 & 56 \\
7 & RTO & 21 & 42 & 29 & 58 \\
8 & Employer Data & 18 & 36 & 32 & 64 \\
9 & Admission in a school & 15 & 30 & 35 & 70 \\
10 & House \& Water tax & 11 & 22 & 39 & 78 \\
11 & Ap raitu runa mafi (agri) & 6 & 12 & 44 & 88
\end{tabular}

\section{Linking of aadaar to voter id, gas cylinder, etc., S.No.}
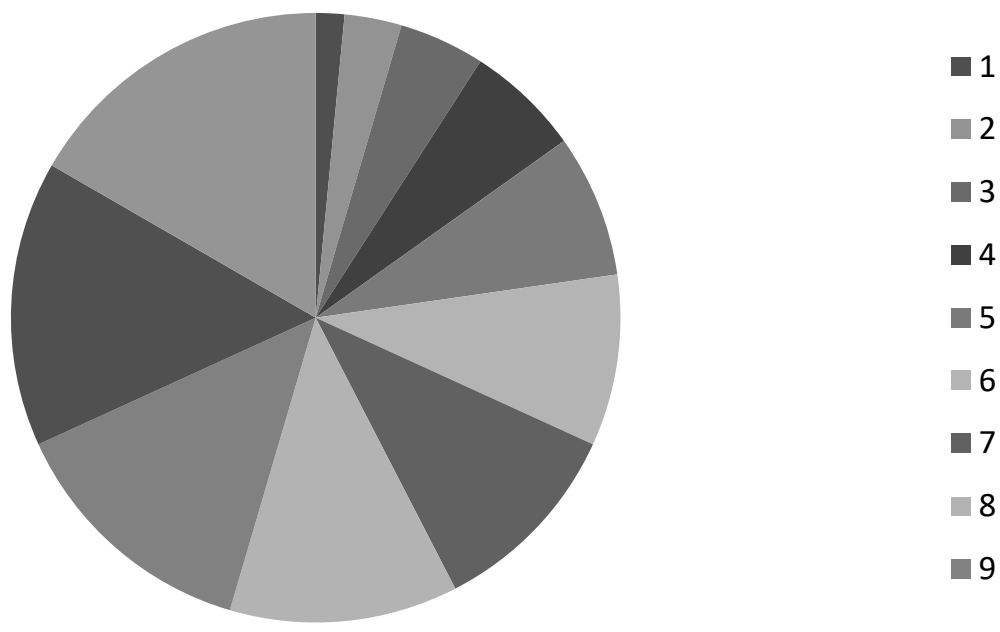

It is found that still linkage is not yet fully completed and in some areas it is high and in some areas it is less. $1^{\text {st }}$ place occupied by bank account, followed by voter id, followed by income/caste/nativity, followed by gas cylinder, followed by fee reimbursement, followed by birth certificate, followed by RTO, followed by employer data, followed by admission in a school, followed by house and water tax and agriculture loan. We can say that linkage of aadhaar to be improved. 
Table 12: How many time Aadhaar used as proof of Identity

\begin{tabular}{|l|l|l|l|l|l|}
\hline S.No. & \multicolumn{1}{|c|}{ Times } & Frequency & Percentage & Valid Percentage & Cumulative \\
\hline 1 & 10 times & 6 & 12 & 12 & 12 \\
\hline 2 & 2 times & 7 & 14 & 14 & 26 \\
\hline 3 & 5 times & 20 & 40 & 40 & 66 \\
\hline 4 & above 10 times & 17 & 34 & 34 & 100 \\
\hline 5 & Total & 50 & 100 & 100 & \\
\hline
\end{tabular}

\section{How many time Aadhar used as proof of Identity Frequency}

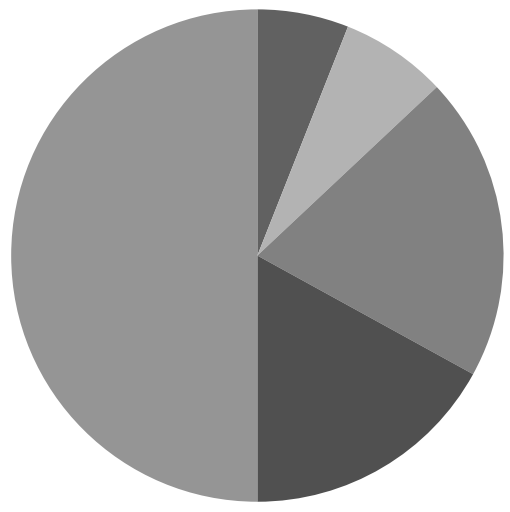

110 times

22 times

35 times

4 above 10 times

5 Total

Table 12 shows the usage of aadhaar by the people out of 50 Majority 20 used 5 times(40\%), followed by 17 used above 10 times(34\%), followed by 7 used 2 times(14\%), followed by 6 used 10 times(12\%). We can understand that usage of aadhaar is day by day going in an increasing trend.

Table 13: Which one is used as proof of Identity \& Address by your choice?

\begin{tabular}{|l|l|l|l|l|l|}
\hline S.No. & Item & Frequency & Percentage & Valid Percentage & Cumulative \\
\hline 1 & Aadhaar Card & 36 & 72 & 72 & 72 \\
\hline 2 & Driving License & 3 & 6 & 6 & 78 \\
\hline 3 & Pan Card & 2 & 4 & 4 & 82 \\
\hline 4 & Ration Card & 6 & 12 & 12 & 94 \\
\hline 5 & Voter Id & 3 & 6 & 6 & 100 \\
\hline & Total & 50 & 100 & 100 & \\
\hline
\end{tabular}




\section{which one is used as proof of Identity \& Address by your choice? Frequency}

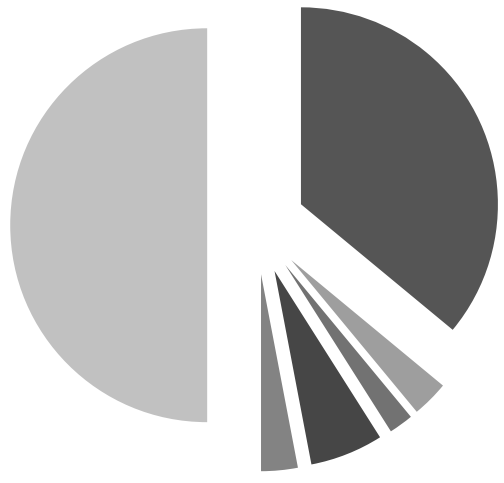

1 Aadhar Card

2 Driving License

3 Pan Card

4 Ration Card

5 Voter Id

5 Total

Table 13 shows the choices of Proof of Identity of their choices. Out of 50 Majority 36 chosen aadhaar as proof of Identity (72\%), followed by 6 with ration card (12\%), followed by 3 driving license and voter identity, followed by 2 pan card (4\%). With this analysis also we can say that usage of aadhaar is high.

Table 14: As per your wish and will do you want that giving Aadhaar numbers to people and linking it to be continued or stop or can't say vote it.

\begin{tabular}{|l|l|l|l|l|l|}
\hline S.No. & Item & Frequency & Percentage & Valid Percentage & Cumulative \\
\hline 1 & Can't Say & 12 & 24 & 24 & 24 \\
\hline 2 & Continue & 38 & 76 & 76 & 100 \\
\hline 3 & Stop & 0 & 0 & 0 & \\
\hline & Total & 50 & 100 & 100 & \\
\hline
\end{tabular}
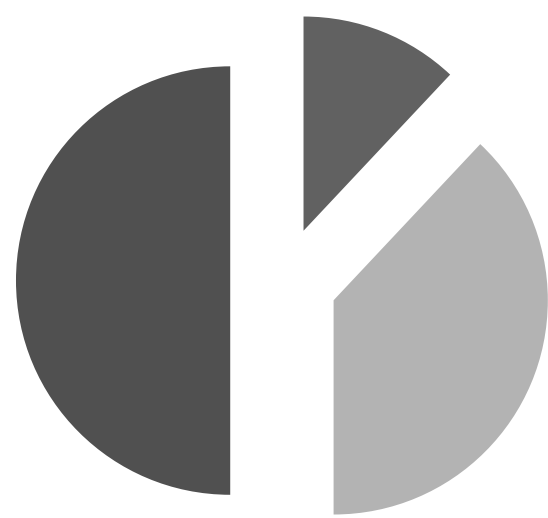

- Can't Say

Continue

Stop

- Total

Table 14 shows the voting results of the people. Out of 50, 38 people majority voting to continue the aadhaar enrolment and linking of aadhaar and 12 people voted against it and willing to stop. 


\section{Summary \& Conclusion}

We can say with the above analysis the linkage, usage of aadhaar is day by day improving and increasing. The majority people accepting the aadhaar and linkage of aadhaar to several government amenities.

\section{References}

[1] http://economictimes.indiatimes.com/topic/Aadhaar

[2] Right to Information Act letter dated 14/08/2014. Reply on 18/08/14

[3] Reply for the letter dated 14/08/2014. Reply on 18/08/14 RTI

[4] http://uidai.gov.in/

[5] http://uidai.gov.in/aapka-aadhaar.html

[6] http://uidai.gov.in/what-is-aadhaar.html

[7] http://www.dhanbank.com/pdf/ploan-documentation.pdf

[8] http://uidai.gov.in/all-about-uidai/mandates-objective.html

[9] http://uidai.gov.in/all-about-uidai/vision,core-values-mission-statement.html

[10] http://uidai.gov.in/all-about-uidai/mandates-objective.html

*Corresponding author.

E-mail address: raju8187@gmail.com 